\title{
Eco-zones Household Socio-economic Differentiation among the Keiyo in Kenya
} Changach JK *

Department of Educational Foundations, Moi University, Kenya

"Corresponding author: Changach JK, Department of Educational Foundations, Moi University, Kenya, Tel: 254721856516; E-mail: jkchangach@yahoo.com

Received date: November 02, 2015, Accepted date: November 07, 2015, Published date: November 16, 2015

Copyright: (c) 2015 Changach JK. This is an open-access article distributed under the terms of the Creative Commons Attribution License, which permits unrestricted use, distribution, and reproduction in any medium, provided the original author and source are credited.

\begin{abstract}
This paper discusses the efforts and actions by the Kenyan government to address challenges of agrarian change and rural transformation in Keiyo. The paper demonstrates that state employs the mechanisms of co-opting the forces of rural commercialization through the strategies of land consolidation. The paper explains that these strategies widen the scope of engagement in the post-colonial economy by Keiyo households. Keiyo households have demonstrated their capacity to respond positively and spontaneously to agrarian changes and innovations which proves vital to the enhancement of their economic well-being. Furthermore, the paper addresses two other issues; first it considers the nature of households as units of study and analysis of rural society. The household has too often been assumed to be a unitary phenomenon, a presumption that ignores intra and inter-household social processes in the allocation of labor, production of goods and services, generation of incomes, spending, consumption and reproduction. This does not imply that the household is an inappropriate unit of study, but rather that the processes that go on within and between households must be sought out and recognized on a case basis. Second, the paper employs data collected from the three ecological zones, in order to examine the characteristics of households in Keiyo; that is; size, composition, the gender of the household head, as well as distribution of household resources within and across the three ecological zones. It is demonstrated that the characteristics of these household reflect the different economic opportunity structures of the three areas. It is suggested that while the distribution of resources within any of the three ecological zones is to varying degrees unequal, there is nevertheless a pronounced pattern of inequality across eco-zones: most households in the highland are better endowed with resources than most households either on the escarpment or in the valley.
\end{abstract}

Keywords: Keiyo; Socio-economic; Differentiation; Eco-zones; Household; Inequality

\section{Introduction}

The three ecological zones in Keiyo are the highland; escarpment and Kerio valley floor. The strategies that individuals and households use in the pursuit of their livelihoods and the activities in which they are engaged are affected by economic differentiation. In this paper, it is suggested that, although diversification of economic activities is a strategy shared by people of all three ecological zones, there are vast differences between these three areas in the ability of people to diversify their enterprises. The paper seeks to demonstrate that, while most people seek to diversify, their ability to do so is limited, to varying degrees, by the opportunity structure of their area.

\section{Research Instruments}

In the selection of the instruments to be used in the study, the researcher ensured that the objectives of the study were clear and well suited to the instrument chosen. The instrument used for data collection was through in-depth interviews and focused group discussion. These methods provided data that was not possible to obtain using questionnaire. Through these methods the researchers clarified questions that were not clear.

Purposive sampling is a non-probability technique which allows the researcher to use cases that provide required information with respect to objectives of the study. In this regard, the sampled respondents provided the requisite information through in-depth interviews and focused group discussion.

\section{The keiyo}

The Keiyo are part of the larger grouping of eight culturally and linguistically related ethnic groups known as the Kalenjin, a heading which includes the Kipsigis, Nandi, Tugen, Marakwet, Pokot, Sabaot and Terik [1]. These groups were earlier known collectively as Nandi speaking peoples or alternatively, as the southern Nilo-Hamites [2]. The more recent name Kalenjin, which translates as "I tell you," is a relatively new historical phenomenon dating to the time around World War II, and stemming from a desire to draw political strength from the larger numbers such an association would bring [3].

\section{Keiyo ecosystem}

A great amount of ecological diversity can be found within a relatively short distance because the Elgeyo Escarpment bisects Keiyo. "The escarpment cuts the Keiyo into two parts of unequal size: a highland part forming roughly two-thirds and a lowland part forming one-third of the district." Keiyo can be divided into three major ecological zones, the highland, escarpment and lower valley [1] (Figure $1)$.

Rainfall in Keiyo varies directly with elevation. In the plateau highlands with elevation of 2,000 meters and above, annual precipitation ranges from 1,200 to 1,700 millimeters per year, while on the floor of the Kerio river valley at 800 to 1,200 meters elevation, average rainfall declines to approximately 800 to 1,000 millimeters per year. On the Elgeyo escarpment itself, at elevations ranging between 
1,200 and 2,000 meters, precipitation is intermediate between the highlands and valley, averaging 1,000 to 1,400 millimeters per year [5].

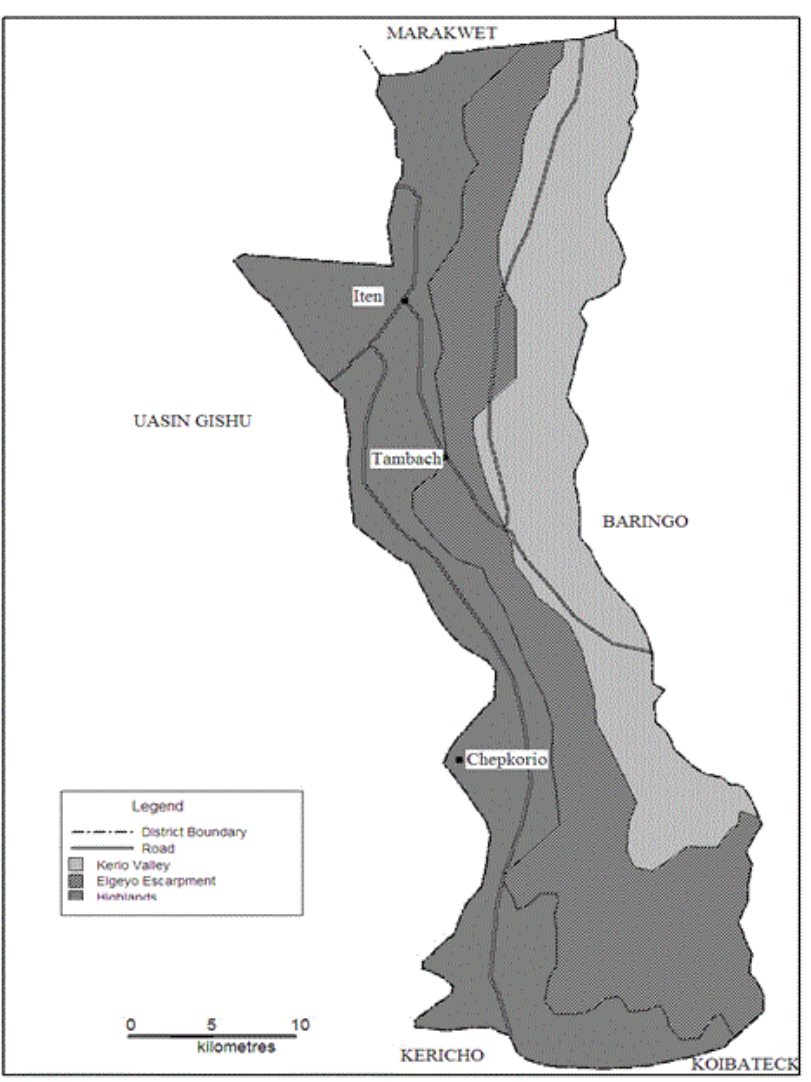

Figure 1: Map showing topographical zones in Keiyo. Source: Oduori [4].

Reflective of these differences in rainfall, natural vegetation in the three zones varies substantially with elevation. In the highlands, the forests are a mixture of indigenous trees such as African pencil cedar and East African yellow-wood, and introduced exotic trees such as Australian Blackwood, blue gum, pine, wattle and cypress. On the escarpment, exotic trees such as cypress are planted in house compounds, but more indigenous species are also found, such as the red hot poker, and croton (Kelelwa). The former, also known in English as Nandi flame, is a strikingly beautiful tree that is the focus of a traditional healing ceremony for treating mumps. Croton leaves are used to brew honey beer (Kipketinik) [6].

It is in the Kerio valley that trees play their most important role. There, drought resistant acacia species, such as Seyal and Mellifera dominate, and many have medicinal uses. Other indigenous trees of importance in the valley include species such as terminalia brownii, the wood of which is termite resistant and is used for making beehives, and desert date (Ngoswo) which yields edible leaves that are usually cooked with meat. Trees, especially acacias, are also important in the valley for the placing of behives [1]. In the Kerio valley, there are two non-cultivated plant species which are of special economic significance. These are prickly pear cactus and sisal species that are well adapted to dry conditions. The fruits of the prickly pear cactus are edible when ripe and provide people, especially children, with food.
Sisal mainly grows wild in many parts of the Kerio valley. Nonetheless, it is opportunistically utilized locally in the manufacture of ropes, and this is a supplementary source of income for women in the lowlands (Figure 2).

\section{Households in keiyo}

Rural households are usually vulnerable because they lack access to sources of subsistence and income. Macroeconomic, institutional and social constraints can mean they are unable to increase their entitlements and assets and thus escape the poverty trap [7]. They face risks because their resource base is often insecure and uncertain from unpredictable weather, the cobwebs of commodity pricing, uncertainties in input supply and costs, the uncertainties of government and landlord pressures over land, and the need to feed increasing numbers of mouths from ever smaller land holdings [8]. The "not-so-poor" can be hit by a combination of these factors and find difficulty in restoring a modest rural income; the "poor" become "very poor" when they experience the same misfortunes. Providing the opportunities so that low income groups can create more secure and sustainable livelihoods will require interventions on and off the farms, co-operation with neighbors, and the understanding and active support of policy makers.

In considering opportunity structures across eco-zones in Keiyo, there is need to examine the nature of households in these different areas to determine whether there is any important differences between eco-zones in the size and composition of households and distribution of resources among households. If so, how might these reflect the different opportunity structures that prevail in each of these areas?

The average size of households in the three ecological zones of Keiyo varies directly with elevation: the largest households are in the highlands, the smallest in the valley, and households of intermediate size are the norm on the escarpment. Households are larger in the highlands because of the greater number of children there than the escarpment or valley.

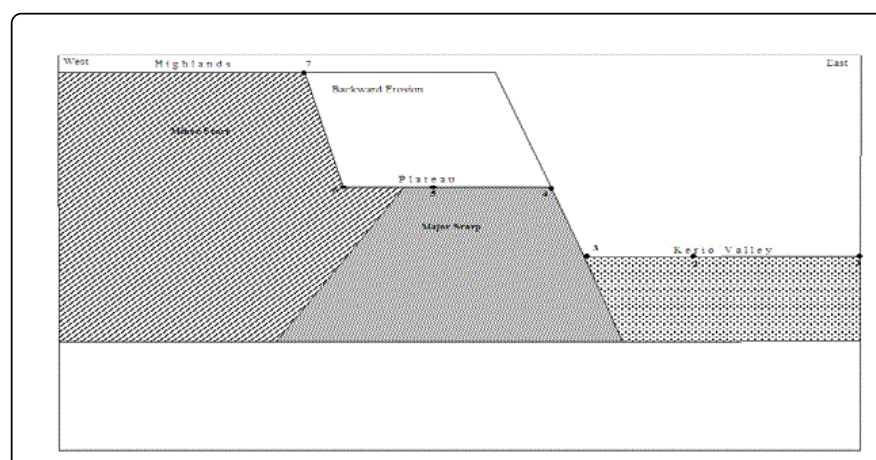

Figure 2: Showing Profile showing the relationship between topography, soil and vegetation. Source: Oduori [4].

This study suggests that because of the more favorable climate for agriculture and better infrastructural development in the highlands, this area was able to support a larger and younger population than either the escarpment or the valley. On average, the households of the highlands are larger by virtue of the more favorable opportunity structure there vis-à-vis those on the escarpment and in the valley.

The structure of household composition reveals something of their social and economic functions. However, cross culturally speaking "the 
household" and "the family" is not necessarily coterminous, nor are they universal. The forms and functions that each take on and carry out varied widely [9]. For purposes of simplicity, the types of families and living arrangements that are discovered during the course of this research were divided into three broad categories: nuclear families (a husband, wife and unmarried children); extended families (possibilities included a husband, wife and married children); polygynous households including a husband, his wives, and unmarried or married children; a husband and wife along with unmarried or married children as well as some additional person(s), usually a relative such as the husband's widowed mother); and other arrangements (a catch all category including single parent families, individuals living alone, and any other arrangements that did not involve a husband and wife/wives).

Nuclear families are by far the most frequent type of household arrangement found across ecological zones. There are no differences between eco-zones in the households that are comprised of nuclear families. The households made up of extended families in the highland are higher than both the escarpment and the valley.

The higher number of extended families in the highlands can be explained as a reflection of the greater concentration of productive resources there. Because of the more favorable opportunity structure there, households are larger and include more children in the highlands than in the other two eco-zones. It is logical that they could also contain a large number of other persons, relatives or otherwise, who had become attached. In the highlands it is a fairly common pattern among elderly couples that, when the husband or wife dies, the surviving member would go to live with one of the children, usually the youngest adult male. This stemmed from the fact that Keiyo inheritance patterns leaned towards ultimo geniture.

In terms of household composition, the "other arrangements" are relatively high both on the escarpment and in the valley, compared to the highlands. A large number of these "other" types of households are comprised of single adults, most often widows, who are living with one or more of their children and/or grandchildren [10].

It is common for a grandchild to stay with his/her grandmother in order to help with farming tasks and household chores. Except on the escarpment and in the valley, it is relatively rare to find a person, elderly or otherwise, living by himself or herself. It can be argued that "the "web" of kinship provides a safety net for the elderly persons.

Traditional Keiyo social relations are patriarchal, descent is traced patrilineally, and residence is patrilocal. To a large extent these statements are still true; nonetheless changes in social and economic processes are making inroads into Keiyo. This is revealed in, among other things, the gender of household heads.

Invariably, even in cases of men who are absent for most of the year, adult males would claim to be the head of the household. Often, however, this is superficial in the daily running of the household. Male headed units comprise the vast majority of households found in all three areas. According to one respondent there are more femaleheaded households in the valley than both the highlands and the escarpment. It is suggested that it is due at least partially to the relatively large number of widows living in the upper reaches of the valley, on the lower part of the escarpment. By living in the upper sections of the valley, it is possible to escape scourges like malaria and sleeping sickness and, therefore, less of a serious threat to life. In addition, there is some water flowing down this lower section of the escarpment in the form of very small streams; this allows some of them to divert the flow of water to their gardens. The older women are less involved in the livestock dominated lifestyles of the valley floor and are known for their continued cultivation of the traditional grain staples of millet and sorghum, in contrast to their virtual replacement by maize on the escarpment shelf and in the highlands. These crops (millet and sorghum) are drought-resistant and grew well on the rocky, thin soils on the slopes of the lower escarpment. There is a niche that the elderly widows occupy between the traditionally male-dominated, pastoralist mode of production of the valley and the mixed farming, larger enterprises of younger families on the upper escarpment.

It is suggested that males in Keiyo are much more likely than females to be engaged in salaried employment away from home. This means that husbands are more likely than wives to be non-resident for part or most of the year. In some cases, especially those of school teachers, men are employed locally. Even if these individuals did not work in the same village where they lived, they are still relatively close to home. Several of the male wage earners of the highland and the escarpment are employed in local primary schools in neighboring villages. These men go to work in the morning, often came home for lunch, and certainly came home in the evening.

In other cases, individuals are employed in towns such as Eldoret, Iten, Tambach, Flourspar, Chepkorio and Flax; they stay there during the week and go home to the village on the weekends. In terms of the role they play in directing the daily affairs of the household these men are probably intermediate between two extremes. In still other cases, men are employed in distant parts of the country; this is especially true of those individuals in the Armed Forces, the Police force, the Administration police or the Prisons. These men spend nearly the entire year away from home, often returning home for a month's holiday. According to Joseph Kimulwa, these men make major decisions concerning resource allocation but their wives would be the ones to make decisions concerning the everyday operations of the household enterprise.

It is clear from this study that the differences between the three ecozones in the female-headed households largely disappeared when male absenteeism is factored in. Female-headed households are more in the highlands than in both the escarpment and valley. It is suggested that this reflect the greater degree of participation in the market economy by the people of the highlands than those people in the valley or escarpment eco-zones.

The study has provided evidence to suggest that the differing nature of economic differentiation in these three areas was manifested in characteristics such as the overall size of households and their composition; households are larger and more likely to include extended families in the highlands. This emerging pattern of economic differentiation is also a function of spatial distribution of resources among the three eco-zones.

\section{Landholdings}

Land is an extremely valuable resource in Keiyo as it is throughout Kenya and rural Africa in general; it forms the basis for agricultural production, including growing crops for food and for sale, as well as keeping livestock for food and market. Therefore, land becomes one of the most critical elements to consider when examining the relative distribution of resources between households and eco-zones. Generally speaking, while well-to-do households possess more land, the quality of land (in terms of arability) is as important as its quantity. 
It is noted that although there are often great differences in the soil types to be found within any one of the three ecological zones, on the whole, the most productive lands are to be found at the foot of the upper escarpment and in the highlands. The soils at the foot of the Elgeyo escarpment are being constantly enriched through erosion of the escarpment. The soils in the highland have been and still are being worked more intensively. Thus, they often require the application of more fertilizer than those on the escarpment near the face of this landform. Nonetheless, the land in the highlands has the dual advantages of being flatter and much less rocky, and it benefited from greater and more predictable precipitation.

The average size of landholdings are largest not in the highlands but rather in the valley. According to Changach [10] this is due to the relatively poor agricultural quality of the land in the valley vis-à-vis the highland. The intermediate size of landholdings on the escarpment are explicable by the sheer lesser amount of land that is available for cultivation there.

It has been suggested that the Keiyo are cultivating on steep slopes. Nonetheless, if given a choice today, most people would choose flat land, especially that in the highlands. Indigenous grains like millet and sorghum, with their shallow root structures, grow relatively well on the thin, rocky soils that characterize much of the escarpment.

The vast majority of households in each of the three villages own less than ten acres of land and therefore the households practice smallholder agriculture. Many households utilize multiple plots for farming, traditionally a common strategy employed by the Keiyo along with many other small farmers in Africa and elsewhere. The landholdings in the highlands are consolidated while those in the valley remain fragmented. The households on the escarpment have other plots within the escarpment. In the valley, households have multiple plots. For most of these households in the valley this means the escarpment plots are used to grow maize.

\section{Livestock holdings}

Livestock has always occupied a very important place in East African societies. They are not only a means of subsistence, they are also repositories of wealth, sources of prestige, and they help create social ties between individuals. The possession of livestock may have had a strong influence on social and political organization [11].

Traditionally, individuals would accumulate wealth in the form of livestock and redistribute this same wealth through the payment of bride wealth. Property rights in livestock, especially cattle, were often multiplex and complicated [12]. Today, the function of livestock are many: they are valuable not only as walking bank accounts and for fulfilling social functions, their liquidity also makes them a ready means of acquiring cash, especially by entrepreneurs who seek to exploit the interface between traditional and market systems.

The importance of livestock and their role in the three ecological zones is varied. In the lower sections of the hot and dry Kerio valley, livestock husbandry, especially of indigenous breeds of cattle and goats is the only feasible pattern of land use in the absence of large amount of capital. Lack of precipitation and its erratic distribution in time and space made attempts to practice rainfed agriculture precarious at best. Keiyo is not well endowed with sources of surface water that would enable farmers to practice irrigation through gravity fed furrows that draw on the few streams tumbling down the escarpment. In the valley, therefore, keeping goats and indigenous cattle is the most viable option for acquiring wealth among poor households. The indigenous animals are more disease and drought resistant than exotic breeds: important considerations in the hot, dry Kerio valley that is infested with disease vectors such as mosquitoes and tsetse flies.

However, in the highlands it is possible to keep grade cattle (exotic breeds such as Ayrshire or Friesian) or crossbreeds, the offspring of an indigenous cow fertilized by the semen of an exotic bull. Changach [10] argues that "the advantage of crossbreeds to the small farmer is the improved milk yields while still retaining some of the hardiness of indigenous animals."

As with so many phenomena, on the escarpment, livestock occupy an intermediate place between their role as a subsistence base for people in the valley and their income generation potential for people in the highlands. Livestock supplement a lifestyle that is based on farming. Animals are kept on the escarpment but not in the same numbers as in those two areas and not with the same earning potential as in the highlands.

The distribution of cattle between households was more equitable in the highlands than in the other two areas. However, just as with land, when examining the livestock holdings of households, it is important to consider not just the quantity but also the quality of the animals. The number of crossbreed cattle a household own is a reflection of both economic and ecological factors. One respondent, had this to says, that grade and crossbreed cattle generally do not fare well in the Kerio valley because of the heat, lack of water, and presence of disease vectors. While indigenous cattle are by no means perfect, they are rather well adapted to the environment of the valley. On the other hand, keeping crossbreed cattle requires more expensive husbandry practices in terms of feeding, preferably a fodder crop such as Napier grass and health care, including more frequent dipping or spraying to protect against tick borne diseases such as East Coast Fever. The number of improved cattle is greater in the highlands than either on the escarpment or in the valley. It is also apparent that there is a marked tendency for households in the highlands to either possess cross-breed or indigenous animals. In the valley, households with crossbred cattle are those, in which these animals are not kept in the valley, instead they are kept with friends or relatives elsewhere. In the escarpment, like the highlands, people tend to either own all crossbred cattle or none at all.

Although not as valuable as cattle, goats are nonetheless still another important resource. Chebet [5] says, goats are most important in the valley and that the number of goats per household is greater in the valley than on the escarpment or in the highlands. East African goats, like other tropical varieties of this species, can be milked but they are kept primarily for meat. They are small but hardy animals that can either graze or browse, thereby making the best use of the sparse natural vegetation in the valley. In large numbers goats can be difficult to confine to one area. On the escarpment and in the highlands, therefore, where crops are more important to livelihood strategies than in the valley, goats become a threat in damaging crops. Thus, with elevation, as the amount of land devoted to crop production increased, goats become less frequent. Like goats, sheep are kept mainly for meat. In absolute terms, sheep are found in greatest numbers in the valley; however their distribution is less equitable in the valley than it is in the highlands.

Donkeys, along with other small animals such as chicken and rabbits, are also reared. Chicken are ubiquitous on the escarpment and in the highlands; almost every household in these areas have some. Donkeys are relatively rare and although used as a beast of burden they 
are not regarded in the same way as other stock. Rabbit husbandry is being encouraged in schools and they are kept mainly by children and their popularity is not yet widespread.

This study suggests that the distribution of total livestock units, like the distribution of sheep and cattle, is more equitable in the highlands than it is in either the valley or the escarpment. Animals are most important for survival in the valley and although they are often found in greater absolute numbers there, the distribution of livestock in the valley is less equitable than it is in the highlands, where they are less important as a source of subsistence and more important as a means of generating income.

\section{Education}

Resources spent on education and training is investment in economic development and in the creation of jobs. Studies undertaken by World Bank show that rates of return to expenditures on education and training in developing countries are very high. Studies specific to Kenya show that farmers and informal sector workers with primary education are one-third more productive than workers who have not had basic education [7]. Therefore, education transforms people by making them more receptive to the practical uses of science and technology in agriculture, industry and services. Further, educating women contributes significantly towards many other desirable objectives such as that of reducing population growth.

In Kenya, there is an almost insatiable demand for education at all levels, to which there has been an impressive response on the part of the government and local communities. Educational opportunities are differentially manifested as a result of the various opportunity structures of these three areas. These opportunity structures influence the ability of parents to purchase school supplies for primary pupils and pay the cost of school levies/fees for secondary school students. Although primary education is government sponsored, parents still buy extra text books, uniforms, writing materials, and other items that are quite costly for them. The secondary school fees take up an enormous share of a household's budget, and are a major concern of a family.

\section{Diversification as an economic strategy}

The most common economic strategy among the Keiyo is to diversify one's activities in order to reduce risk and uncertainty [13]. This is a well-known and common feature of small holder farmers in many parts of the world. But not all activities are equal in terms of their ability to minimize risk/uncertainty or their profitability. Farming and animal husbandry (agriculture) are basic to and essential for making a living in Keiyo. But agriculture is ultimately dependent upon an often unpredictable environment, most importantly the timing and amount of rainfall. For most people, because of the lack of capital, agriculture and agricultural related on-farm activities are all that they are able to engage in. But this puts them at risk, so in carrying out those activities, they strive to diversify them through the types, numbers, and locations of crops grown, the types, numbers and location of animals kept, and the types of supplemental activities performed, such as producing and selling charcoal.

A few individuals and households are able to supplement their onfarm income from agriculture and managed to reduce the uncertainty of farming with money earned from off-farm pursuits, such as salaried employment and business endeavors. Those individuals and households, especially those able to combine earnings from a government job and business with income generated from agriculture, prove most successful and well-to-do by any standards and exemplified the goal of development [14].

Development is reflected in material indicators such as modern housing style and construction, possession of consumer goods, land and livestock holdings, but also in the ability to educate children. Just as with efforts to reduce uncertainty, people also sought to achieve the goal of development through diversification of income-generating activities. But the ability to diversify is differentially manifested both among and within ecological zones.

It has been demonstrated that the reasons for differences in ability to diversify are partly ecological, related to the differing micro ecologies of the three eco-zones of the highlands; the escarpment face, and the valley, and partly historical, related to the colonial government's perception of the land-use potential of the three areas and how this affected their dealings with the inhabitants of these zones. The perception of the differing land-use potential of the three areas led to their differential statement in terms of development efforts. This fundamentally has altered the land-use practices of the Keiyo and greatly exacerbated a pre-existing tendency for the highlands to be the most economically productive area. This pattern has been constantly reinforced in the post-colonial era and continues to date.

Previously the Keiyo inhabited the face of the Elgeyo Escarpment while utilizing the valley floor and the forest at the top of the escarpment for grazing livestock. The rocky escarpment provided safety from the disease vectors in the hot, arid Kerio Valley as well as the human threat posed by the Nandi and Uasin Gishu Maasai in the cool, wet highlands plateau. During the colonial period, many Keiyo moved up from the valley into the highlands where they took up work on settler farms and where some could even get access to land in the narrow strip of plateau continued within the district. This started a process whereby the highlands become favored in terms of development at the expense of the valley not only by the British colonial administration, but also by the independent Kenyan government and the Keiyo themselves. This process has continued to the present and is reflected in the demographic composition, material affluence and activities of the three eco-zones [15].

Nonetheless, it is argued that the whole of the contemporary situation is not solely determined by history and ecology. Clearly there are individuals and households on the escarpment and in the valley, as well as those in the highlands, who are able to diversify their economic activities and thus approach the common goal of development held by most, if not all, people today. However, in most cases, those individuals and households in the valley and on the escarpment do not rely on the resources of a single eco-zone. Rather, in diversifying their income generating activities they follow a traditional pattern of utilizing multiple agricultural plots, as well as relying on more recent innovations such as wage labor and business enterprises.

The economic differentiation of the three ecological zones of Southern Keiyo affect the ways that people from each of these areas perceive their "situational logic," that their position in the power and wealth structure in terms of access to and control over resources. Specifically, the differential resource distribution between ecological zones is reflected in varying perceptions of economic security. In essence, although there are exceptions, generally the people of the highlands seem to feel more comfortable with their economic situation than people on the escarpment and in the valley. Changach [10] asserted that the economic opportunity structures of those three areas 
affected how people felt about their situations. Particularly, the more productive economic opportunity structure of the highlands means that a greater degree of perceived economic security is manifested there than in the other two areas. It is noted that, in terms of resource distribution between ecological zones, as a group, households in the highlands are the most well-off of the three ecological zones.

The occupation of people in the three ecological zones of Keiyo is also a reflection of economic opportunity structure. Although people seek to diversify their economic activities and sources of income, most adults in the area are primarily farmers. Nonetheless, there are a small number of persons who have other sources of income. Occupation can be categorized into four: farmers, student, wage laborer, and entrepreneur. The category "farmer" should be "full-time" farmer, since even those who were engaged in wage labor or business endeavors almost always retain their farms, which are worked by family members and, to a lesser extent, which they worked themselves $[16,17]$.

The category "wage laborer" includes a wide variety of work under a relatively simple heading. Most wage laborer in this areas include local teachers, civil servants, drivers of commuter vehicles (matatus) or trucks, security guards, clerks, grounds men in schools, farm helps, and among many others.

"Entrepreneurs" are persons who are engaged in a financially remunerative business activity or set of activities. This is predictably, the smallest of the four occupational categories. However, here again there are differences across the three eco-zones. The entrepreneurs sell a wide variety of goods in shops including cooking fat, soap, sodas, and clothes.

It is important to mention that the number of people engaged in wage labor is a function of two factors; first, access to source of employment is greatest in the highlands, since Eldoret, is 35 kilometers away. It is a source of employment for all categories.

\section{Conclusion}

The discussion of households in Keiyo, considered their size and composition, as well as the distribution of household resources across the three ecological zones under consideration. To review this discussion, it was found that, in terms of land and livestock holdings, the highlands ecological zone is definitely the most favorable one, with the valley the least and the escarpment intermediate. While there were certainly affluent, prosperous households on the escarpment and in the valley, they were much fewer in number than in the highlands. It is suggested that, as a reflection of the more favorable economic opportunity structure there, the distribution of resources was more equitable among households in the highlands than either of the other two areas.

The different economic opportunity structures of these three areas were reflected in the make-up of households. On average, households were largest in the highlands, smallest in the valley and intermediate on the escarpment. This was due to the fact that the population of the highlands was younger and that there were more children there than in the other two areas.

This study has also examined the economic strategies that people from the three ecological zones in southern Keiyo used and the activities in which they engaged to make a living. The study has endeavored to show that people felt most secure in the highlands and that they were better able to meet their own economic expectations there than elsewhere. It has also been suggested that the economic strategies of people in these three ecological zones led them to deliberately seek to diversify their economic activities both in order to reduce risk/uncertainty and also in the attempt to turn a profit. In this regard, those households that were able to combine on-farm activities with off-farm sources of income were generally the most successful and secure. However, the ability to diversify was not equally distributed. It was dependent upon access to capital and as such it tends to be greatest in the highlands. Nevertheless, the economic opportunity structure of the highlands was so benevolent that people there could succeed without extensively diversifying, whereas for households on the escarpment and the valley, diversification was a prerequisite for economic success.

Households from those three ecological zones engaged in a wide variety of economic activities: farming, animal husbandry, casual labor and charcoal burning and sale, wage labor/salaried employment, and entrepreneurial/business endeavors. Generally, the amount of money that could be earned from any one or more of these categories was greatest in the highlands, intermediate on the escarpment, and least in the valley. Total income from all sources combined clearly correlated directly with elevation.

It is demonstrated from this study, that the perceived economic security and ability to meet one's own economic expectations were also greatest in the highlands. These differences were not the result of varying attitudes towards the desirability of "development". The better life that people enjoyed in the highlands was and is aspired to by nearly all people today. However, with the exception of a few well-to-do individuals in the valley and on the escarpment, this standard of living was generally available only to those fortunate enough to be endowed with the right mix of resources: the residents of the highlands.

\section{References}

1. Changach JK (2011) Agro-Pastoralism in Kenya. Academic Publishing GmbH \& Co. KG, Verlag, Lap Lambert, Deutschland.

2. Kipkorir BE (1973) The Marakwet of Kenya-A Preliminary Study. Kenya Literature Bureau, Nairobi.

3. Huntingford GWB (1963) The People of the Interior of East Africa by its Modern Inhabitants. In: Oliver R, Mathews G (eds.) History of East Africa. Oxford Clarendon Press 1.

4. Simon MO (1991) Land-Use in Elgeyo (Keiyo) Marakwet District. Ministry of Planning and National Development, Technology Report.

5. Susan C, Dietz T (2000) Climbing the Cliff-A History of the Keiyo. Moi University Press, Eldoret.

6. Sutton JEG (1976) The Kalenjin. In: Ogot BA (eds.) Kenya before 1900. East African Publishing House, Nairobi.

7. Republic of Kenya (1991) Development and Employment in Kenya-A strategy for the transformation of the Economy-Report of the Presidential Committee on employment. Government Printer, Nairobi.

8. Republic of Kenya (1991) Office of the President. Department of Development Co-ordination-National Poverty Eradication Plan, 1999-2015. Government Printer, Nairobi.

9. Helge K (1977) Ecology Control and Economic Development in East African History. Heinemann, London.

10. Changach JK (2011) Economic Opportunities and Differentiation in Kenya. Academic Publishing GmbH \& Co. KG, Verlag, Lap Lambert, Deutschland.

11. Harold KS (1979) Livestock and Equality in East Africa-The Economic Basis for Social Structure. Indiana University Press, Bloomington.

12. Massam JA (1968) The Cliff Dwellers of Kenya. Frank Cass and Company, London. 
Citation: Changach JK (2015) Eco-zones Household Socio-economic Differentiation among the Keiyo in Kenya. Arts Social Sci J 6: 135. doi: 10.4172/2151-6200.1000135

Page 7 of 7

13. Bates RH (1989) Beyond the Miracle of the Market-The Political Economy of Agrarian Development in Kenya. Cambridge University Press, Cambridge.

14. Bates RB, Lofchie MF (1980) Agricultural Development in Africa-Issues of Public Policy. Praeger, New York.

15. Robert MM (2003) Going their Separate Ways-Agrarian Transformation in Kenya, 1930 -1950. Associated University Press, London.
16. Berman BJ (1990) Control and Crisis in Colonial Kenya-The Dialectic of Domination. Heinemann Kenya Ltd, Nairobi.

17. Bruce JB, John L (1990) Unhappy Valley-Conflict in Kenya and Africa. Heinemann Kenya Ltd, Nairobi. 